\title{
Chapter 14 \\ The Girgentana Goat Breed: \\ A Zootechnical Overview on Genetics, \\ Nutrition and Dairy Production Aspects
}

\author{
Salvatore Mastrangelo and Adriana Bonanno
}

\begin{abstract}
In recent years, there has been a great interest in recovering and preserving local livestock breeds. An interesting situation is represented by the Girgentana goat, an ancient local breed reared in Sicily. Over recent years, this breed has become almost extinct, in part as a consequence of the marked decrease in fresh goat milk consumption. On the basis of these considerations, several studies on its genetic structure and management aspects have been conducted in order to protect the Girgentana goat from the risk of extinction and recover its genetic and economic value. In this context, information on genetics, nutrition and dairy production aspects may have a crucial role in the improvement and management of the breed. Thus, this chapter describes some points of these applications through recent investigations on this goat breed.
\end{abstract}

\subsection{Introduction}

The domestic goat (Capra hircus) has been a source of milk, meat, skin and fiber since its domestication, occurred about 10,000 years ago in, at least, two main centres in the Middle East (Zeder and Hesse 2000; Naderi et al. 2008). Different goat populations evolved over the time in different environments thanks to their ability to adapt to extreme conditions, ranging from high mountains to desert. Nevertheless, goat species has a wide and largely unknown genetic potential that could be better exploited in sustainable agriculture. The most common goat breeds in Europe are specialized in the production of milk. So that, in some areas, the goat cheese-making sector holds an appreciable economic value from South to the North Europe. In most of the Mediterranean area, the population demography, the persistence of the traditional factors of breeding and the poor economic interest towards the goat breeding have led to the spread of semi-extensive system

\footnotetext{
S. Mastrangelo $(\bowtie) \cdot$ A. Bonanno

Dipartimento Scienze Agrarie e Forestali,

Università degli Studi di Palermo, 90128 Palermo, Italy

e-mail: salvatore.mastrangelo@unipa.it
} 
characterized by a substantial dependence on the grazing resources (Criscione et al. 2016). The traditional local populations, well adapted to harsh conditions, are scarcely managed, with rare or unconsolidated herd books (Canon et al. 2006).

In the mountainous areas of Italy, a large number of local goat breeds is still found, suggesting that there is considerable genetic variability in Italian goats (Nicoloso et al. 2015). Because the existence of a large gene pool is important for the potential future breeding preservation and for sustainable animal production system development, concerns about the conservation of genetic variability have arisen in the last years. The combination of biodiversity and quality of products is, therefore, a current issue (Martini et al. 2010). Therefore, the conservation and monitoring of the genetic diversity of these local breeds are fundamental to meet future breeding needs, especially in the context of a global climate change (Mastrangelo et al. 2017a). An interesting situation is represented by an ancient and rare local breed reared in Sicily, the Girgentana goat breed.

\subsection{General Aspects of the Breed}

\subsubsection{Origins and History}

The Girgentana breed (Fig. 14.1) originates probably from Afghanistan and the Himalaya regions from markhor (Capra falconeri, a wild species more closely related to domestic goats) and was established in the south-west of Sicily, in particular in the area around Agrigento. In fact, the presence of screw-shaped horns similar to those of the markhor and of some highly divergent mtDNA haplotypes (Sardina et al. 2006) seemed to suggest an Asian origin (Ajmone-Marsan et al. 2014). In addition to the characteristic long corkscrew horns, the breed has a primarily white with grey-brown hair around the head and throat. Traditionally,

Fig. 14.1 A flock of Girgentana goats (provided by Adriana Bonanno)

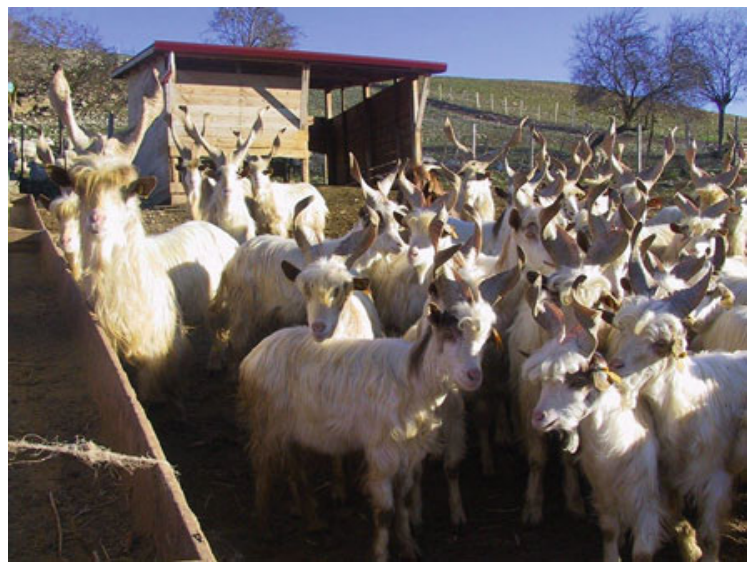


breeding took place in urban farms where the animals were kept in the farmer's house; here, the goats, after coming back from pasture, were tethered in individual wooden stalls, a housing system that Girgentana farmers considered necessary to avoid aggressive and harmful behaviour among animals, due to the presence of their horns. The profit was based on direct retail (door to door sales) of milk used for human consumption. According to the tales of older farmers born in families with a long history of breeding, the milk was primarily used for the nourishment of infants and elderly (Portolano et al. 2004). The imposition of sanitary regulations prohibited both the breeding of these animals within urban farms, and the direct sale of the milk.

\subsubsection{Breeding Systems}

The farms are small and medium-sized and the business is commonly familiar and single-worker types. Semi-extensive farming is generally practiced by all farmers: goats graze during the morning and are housed during the night. In winter months (from November to March-April), the goats are housed indoors and mainly fed with local hay. As soon as fresh grass is available, the flocks are moved outdoors and the goats graze on pastures located near the farms.

The feeding system is mostly based on local fresh and conserved forages. The breed is generally reared in a pastoral system, hand-milked and in the absence of modern husbandry. The absence of milking machine is probably due to the small flock size which does not justify such investment. After kids' weaning, goat milk is processed into fresh and matured cheeses and directly sold to consumers.

$\mathrm{AI}$ is not used and natural mating occurs with the introduction of a buck in the flock. The first delivery usually happens around 1 year of age. Mating season aims at converging kidding in autumn-winter months to ensure the availability of kids in Christmas and, particularly, in Easter times. The length of the productive career of females is high (6-8 yrs.). Kids remain with their mother until slaughtering, at an average age of 50 days and ranging from 10 to $15 \mathrm{~kg}$ of live weight.

\subsubsection{Current Census}

Over recent years, this breed has become almost extinct, in part as a consequence of the marked decrease in fresh goat milk consumption. In fact, it is listed by the Food and Agriculture Organization with an endangered risk status (Canón et al. 2006). The endangered status of the Girgentana breed is linked to the following peculiarities: in 1983, the population consisted of 30,000 goats, while 10 years later, almost $98 \%$ of the pre-existing population disappeared. In 2001, only 252 mature 
goats participated in the national milk recording system (Portolano et al. 2004) and nowadays, only 1500 heads, reared almost exclusively in central Sicily, are enrolled in the Herd Book (ASSONAPA 2014).

\subsubsection{Milk Production Traits}

The main purpose of Girgentana goat is milk production. A descriptive statistics for milk production traits were recently reported in a study conducted on more than 300 individuals from different farms located in different areas of Sicily (Mastrangelo et al. 2017b) (Table 14.1). The authors reported a high variability in milk yield, which varied from less than 1000 to $\sim 4500$ g/goat per day. Although the threshold for somatic cells count (SCC) in goat's milk has not yet been established, the average SCC found in Girgentana goat milk, before being transformed into log value, was greater than the threshold of 1,500,000 cells $/ \mathrm{mL}$ advised in Europe for fresh milk (Delgado-Pertiñez et al. 2003), with a high variability in the breed (Table 14.1). Another study on the physical and chemical composition, and clotting properties (Todaro et al. 2005) reported that the milk pH (6.59 $\pm 0.12 ; \pm$ S.D.) and titratable acidity $(3.36 \pm 0.49)$ were within the normal range for fresh goat milk, with a milk urea content of $43.7 \pm 8.3 \mathrm{mg} / \mathrm{dL}$. The clotting ability of Girgentana milk is quite good, with a renneting time equal to $17.0 \pm 3.1 \mathrm{~min}$, a rate of curd formation of $2.0 \pm 1.6 \mathrm{~min}$ and a curd firmness of $25.1 \pm 7.7$ millimetres (Todaro et al. 2005). In milk of the Girgentana goat, the sum of short and medium chain fatty acids (FA) accounted on about $35 \mathrm{~g} / 100 \mathrm{~g}$ of total FA respectively (Bonanno et al. 2013b; Mastrangelo et al. 2017b); these FA, which include caproic (C6:0), caprylic (C8:0), capric (C10:0) and lauric (C12:0) acids, are the most characteristic in goat milk and derived dairy products, being more abundant than in cow milk FA profile, and are associated with the characteristic flavours of cheeses and can also be used to detect admixtures of milk from different species (Park et al. 2007).

Table 14.1 Descriptive statistics of yield and composition of Girgentana goat milk (Mastrangelo et al. 2017b)

\begin{tabular}{l|l|l|l|l}
\hline Traits & Mean \pm S.D. & Max & Min & Variation coefficient $(\%)$ \\
\hline Milk yield $(\mathrm{g})$ & $1448 \pm 404$ & 4544 & 508 & 28 \\
\hline Fat $(\%)$ & $4.3 \pm 0.9$ & 7.7 & 1.8 & 20 \\
\hline Protein $(\%)$ & $3.7 \pm 0.4$ & 6.5 & 2.4 & 12 \\
\hline Casein $(\%)$ & $3.1 \pm 0.4$ & 5.2 & 1.9 & 13 \\
\hline Lactose $(\%)$ & $4.7 \pm 0.3$ & 5.5 & 3.5 & 5 \\
\hline SCC $\left(\log _{10}\right)$ & $5.78 \pm 0.61$ & 7.28 & 4.47 & 11 \\
\hline
\end{tabular}




\subsection{Genetic Characterization}

\subsubsection{Genetic Diversity and Population Structure}

The investigation of genetic diversity at the molecular level has been proposed as a valuable complement to the evaluation of phenotypes and production systems, and sometimes as a proxy for phenotypic diversity of local breeds. Traditionally, the molecular phylogeny of livestock species has been based on the characterization of the mtDNA (Ajmone-Marsan et al. 2014). In goats, the first studies based on this region highlighted the existence of several well-differentiated maternal lineages, whose variability has a lower geographic structure compared to other livestock species. A previous study on phylogenetic analysis of Sicilian goats using mitochondrial hypervariable region 1 showed that Girgentana haplotypes were highly divergent from the Capra hircus clade. This result could be explained assuming a new mtDNA lineage or a historical introgression from wild goats (Sardina et al. 2006).

Several studies have been performed in order to understand the genetic diversity and population structure in Girgentana breed using molecular markers, such as microsatellites (Canon et al. 2006; Siwek et al. 2011; Negrini et al. 2012). Being highly polymorphic, microsatellites are very informative markers and have been extensively used in diversity studies. Recently, an investigation conducted on population genetic structure of Girgentana goat using microsatellite markers showed a moderate genetic variation and a complex genetic structure because its genome was shared among subpopulations, whereas recent bottleneck has not been detected in the Girgentana goat population (Mastrangelo et al. 2017b). Similar results for this breed were also reported by Pariset et al. (2006) and Mastrangelo et al. (2013a). Moreover, another recent study (Criscione et al. 2016) reported that among South Italian goats, the Girgentana is the breed with the lowest genetic diversity and more seriously threatened because of its very low number and because it is reared almost exclusively in central Sicily, especially by older farmers. In fact, Sicilian goats have shown strong population admixture structure caused by geographical location of the farms, influences of natural mating and traditional breeding systems where the flock is an important breeding unit (Siwek et al. 2011). In many local breeds such as the Girgentana one, selection programmes are absent, only natural mating is the common practice, and the exchange of males among herds is quite unusual (Mastrangelo et al. 2012). This leads to an increase of inbreeding within the population due to mating among relatives and could generate population subdivision as a consequence of genetic drift.

The application of recently developed genomic technology has great potential to increase our understanding of the genetic architecture of complex traits, to improve selection efficiency in domestic animals through genomic selection and to conduct association studies. An investigation on genetic diversity of Italian goat breeds assessing with a medium-density SNP chip revealed and corroborated the 
separation of Girgentana from the other goat breeds and a low genetic diversity (Nicoloso et al. 2015).

Thus, efforts should be made to improve genetic diversity in Girgentana breed. This breed should be monitored due to the low number of individuals that compose it. In particular, mating decisions will play an important role in limiting the levels of inbreeding and would increase the size of this breed.

\subsubsection{Casein Genes}

Caseins are the main protein component of milk, and are highly polymorphic. The high degree of variability, together with post-translational modifications and differential splicing patterns, have qualitative and quantitative effects on milk composition thereby affecting chemical, physical and technological properties of goat milk (Martin et al. 2002; Marletta et al. 2007). Knowledge of variation of casein genes at the haplotype level has been a useful tool in biodiversity studies and in breeding strategies (Caroli et al. 2009).

At CSN1S1, the most frequent alleles in Girgentana goat are A and F followed by $\mathrm{B}$ and $\mathrm{N}$, whereas the most common genotype is $\mathrm{AF}$ followed by AA (Mastrangelo et al. 2013b). At CSN1S2, the most frequent alleles are A, followed by $\mathrm{F}, \mathrm{C}$ and $\mathrm{E}$, whereas the most common genotypes are AA, AF and AC (Palmeri et al. 2014). Tortorici et al. (2014) showed the presence of C, C1 and A strong alleles, and 0' null allele at CSN2 gene, whereas the most common genotypes are $\mathrm{CC} 1$ followed by $\mathrm{CC}, \mathrm{C} 1 \mathrm{C} 1$ and $\mathrm{C}^{\prime}$. The exon 4 of $\mathrm{CSN} 3$ gene was sequenced and analysed by Di Gerlando et al. (2015). Analyses of the obtained sequences showed the presence of A, B, D and G known alleles and two new genetic variants, named $\mathrm{D}^{\prime}$ and $\mathrm{N}$. The most common genotype is $\mathrm{AB}$ followed by $\mathrm{AA}, \mathrm{AD}$ and $\mathrm{BB}$.

The Girgentana goat was characterized by an interesting and wide variability in the casein cluster, with haplotypes rarely found in other breeds, containing the $\mathrm{N}$ allele at the CSN1S1 locus (Mastrangelo et al. 2017b), which has been reported in a few breeds, such as Tunisian goats (Vacca et al. 2009). It is well known that goat caseins are characterized by different expression levels due to strong, medium, weak or null alleles responsible for high, medium or low casein content in milk, depending on the casein fraction (Caroli et al. 2006). Haplotype analysis of the casein genes allows for selection of goat genetic lines for milk production with 'particular' protein content (Sacchi et al. 2005; Mastrangelo et al. 2017b). The high frequency of haplotypes containing strong alleles at each casein gene indicates that selection for these variants should be an easy breeding objective to improve milk composition and cheese-making properties in the Girgentana breed (Mastrangelo et al. 2017b). However, the occurrence of haplotype combinations with null and weak alleles, as $\mathrm{N}$ and $\mathrm{F}$ at $C S N 1 S 1$ and $0^{\prime}$ at CSN2 loci, encloses a high productive potential, because goats carrying these alleles may produce milk with low protein content, which can be used for fresh milk consumption, potentially reducing the risk of developing food allergies. 


\subsubsection{Genetic Traceability of Girgentana Goat Dairy Products}

Local livestock production represents an important resource for the economy of hilly and mountain areas, in which other economic activities are limited. Moreover, in these areas, many typical dairy and meat products have been developed, often linked to one local breed/population (Scintu and Piredda 2007). Consequently, another important aspect to underline is the valorization of the typical products. Breed genetic traceability is becoming an important issue for the authentication of these products, as there is an increasing interest in marketing mono-breed-labelled lines of meat as well as dairy products, which in some cases have obtained the Protected Designation of Origin (PDO) or Protected Geographical Indication (PGI). Genetic traceability is based on the identification of both animal and their products through the study of DNA. This interest derives from the fact that a marketing link between breeds and their originated products can contribute to improve breed profitability and sustainability of such farm animal production with significant impact on the rural economy of particular geographic areas and on breed conservation and biodiversity (Russo et al. 2007). This means that breed genetic traceability is important for both to defend and valorize particular food products and livestock breeds.

With the goal of developing a breed genetic traceability system for Girgentana dairy products, specific microsatellite markers were identified (Sardina et al. 2015). Some microsatellite markers showed alleles present at the same time in Maltese and Derivata di Siria (the most important goat breeds reared in Sicily) and absent in Girgentana and, therefore, they were tested on DNA pools of the three breeds. Considering the electropherograms' results, FCB20, SRCRSP5 and TGLA122 markers were tested on DNA samples extracted from cheeses of Girgentana goat breed. These three microsatellite markers will be applied in a breed genetic traceability system of Girgentana dairy products in order to detect adulteration due to Maltese and Derivata di Siria goat breeds, and can represent a first deterrent against fraud and an important tool for the valorization of Girgentana breed (Sardina et al. 2015).

\subsection{Management Implications}

\subsubsection{Housing System}

The decrease of the Girgentana population has been linked to the prohibition to keep the animals within urban areas, which implied the abandon of the direct sale of milk, also to the difficult management of these goats, due to the presence of their long horns. On the other hand, the traditional housing system in tie-stalls, increasing manpower, contributed to limit the increase in size within Girgentana's 
herds. In this view, the protection actions engaged in order to safeguard this breed from extinction and to recover its genetic and economic value have been combined with studies aimed to define the feeding and production responses of Girgentana goats to more sustainable management systems.

Accordingly, it has been proven the good adaptation of Girgentana goats to free housing within wide straw-bedded pen, evaluated by comparing immunological, endocrine, behavioural and productive responses with those of goats tethered in stalls (Di Grigoli et al. 2003). The individual stalls induced a good state of well-being and a slightly higher milk yield, connected to the possibility of individual feeding, the absence of the competition due to the social hierarchy and the lower energy expenditure for the movement. Nevertheless, ensuring adequate hygiene and enough space, the free housing allowed the goats to move freely, engage social relationships and improve their immune responses and milk quality, whereas the lower milk yield would be compensated by a reduction in manpower.

\subsubsection{Grazing Management}

For the length of their horns, the Girgentana goats are poorly adapted to the exploitation of wooded areas by grazing. Thus, it is advantageous to develop more intensive grazing systems based on forage crops that can ensure the Girgentana goats to express the selective behaviour and voluntary feed intake, meet the nutritional needs and enhance the milk production. With this in view, the grazing management implies to establish the forage species to be grown, the grazing technique and the stocking rate to be applied.

With regard to forage species, the Girgentana goats prefer to graze multi-species pastures than mono-specific ones, since the availability of different complementary forage species allows them to select the parts of plants on the basis of palatability and nutrients content (Baumont et al. 2000), and consequently increase the dry matter and protein intake (Bonanno et al. 2008). Also grass-legume bicultures, compared to the relative monocultures, offer the advantage of greater and better-quality forage biomass, allowing the goats to increase the forage intake and milk yield (Bonanno et al. 2008). Girgentana goats fed Sulla fresh forage (Sulla coronarium, L.), containing phenolic compounds with antioxidant activity, especially condensed tannins, which showed to increase milk yield and casein content (Bonanno et al. 2013a), improve the health properties of milk fat, that was enriched of conjugated linoleic acid (CLA), odd- and branched chain, polyunsaturated and omega-3 FA (Bonanno et al. 2013b) and enhance their oxidative status and the antioxidant capacity of milk, suggesting a transfer of polyphenols from plasma to milk (Di Trana et al. 2015). Accordingly, feeding Sulla forage represents a promising strategy to improve the health status of the animals, milk production and the beneficial properties of dairy products for the consumers' health.

In relation to the grazing technique, the rotational system applied for Girgentana goats grazing on herbaceous pastures did not show to ensure the theoretical 
advantageous in terms of grass availability, intake level and milk yield (Bonanno et al. 2008); therefore, also the continuous grazing can be suitable, simplifying the flock management practices. Whereas moderate stocking rates of 48-50 heads/ha adopted for Girgentana goats grazing herbaceous cultures, such as a sword of ryegrass and berseem clover (Bonanno et al. 2007a) or a sulla meadow (Sulla coronarium, L.) (Bonanno et al. 2007b), resulted to have better impacts on forage resources and goats selective behaviour, forage intake and milk production.

\subsubsection{Relationships Between Nutrition and Genetic Polymorphisms of Milk Caseins}

As well known, both nutritional and genetic factors influence milk yield, composition and technological properties. Thus, in order to contribute to valorization of Girgentana breed, the milk production traits of goats have been defined in relation to the genetic polymorphism of milk casein, with particular regard to $\alpha_{\mathrm{s} 1 \text {-casein, }}$ and taking into account the interactions with nutritional aspects.

With regard to polymorphism at CSN1S1 loci, as the goats of other breeds, also the Girgentana goats with strong alleles associated with a high synthesis rate of $\alpha_{\mathrm{s} 1^{-}}$ casein (HC) (Sacchi et al. 2005) produced, in comparison with goats carrying alleles for medium (MC) or low $\alpha_{\mathrm{s} 1}$-casein (LC), a greater amount of milk (967 vs. 1131 and $1096 \mathrm{~g} /$ day, for LC, MC and HC respectively) showing higher percentage of casein (2.7 vs. 3.0 vs. $3.1 \mathrm{~g} / 100 \mathrm{~g}$ milk, for LC, MC and HC respectively), longer curd firming time $\left(\mathrm{k}_{20}\right)$ and firmer curd $\left(\mathrm{a}_{30}\right)$, that denote a better milk ability for cheese-making (Bonanno et al. 2007c). Moreover, the study of the effects of some composite genotypes at CSN1S1 and CSN3 loci evidenced the additional role of $\mathrm{B}^{\mathrm{IEF}}$ alleles of $\kappa$-casein in further increasing casein content and improving coagulation properties of milk of Girgentana goats with strong alleles of $\alpha_{\mathrm{s} 1}$-casein (Bonanno et al. 2009). These investigations confirmed the higher efficiency of dietary nitrogen utilization in goats with CSN1S1 genotype for high milk casein synthesis (De la Torre Adarve et al. 2009), and evidenced how goats of different CSN1S1 genotype could respond differently to a high energy intake in terms of milk manufacturing properties (Bonanno et al. 2007c), suggesting a possible interaction between feeding regime and CSN1S1 genotype due to implications at hormonal or metabolic levels.

On this basis, successive studies (Bonanno et al. 2013a, b) aimed to investigate the impact of nutrition on the two most common CSN1S1 genotypes of Girgentana breed, which were AA and the heterozygous AF (Palmeri et al. 2014), associated with a high and an intermediate $\alpha_{\mathrm{s} 1}$-casein synthesis respectively. The AA goats exhibited a more efficient use of dietary energy and protein and, consequently, a higher milk yield (1720 vs. 1606 g/day) when fed diets with high energy level and a balanced protein to energy ratio (Bonanno et al. 2013a). This superior efficiency in energy and protein utilization was already revealed at the digestive level, suggesting 
a positive influence of AA genotype to the expression of genes coding for the synthesis of digestive enzymes, rather than implications at level of rumen or mammary gland. The higher $\alpha_{\mathrm{s} 1}$-casein content in milk from AA goats, compared to the AF milk (0.7 vs. $0.6 \mathrm{~g} / 100 \mathrm{~g}$ milk), emerged independently of diet and was responsible for the improved milk properties, as a result of the longer coagulation time (r, 15.2 vs. $13.9 \mathrm{~min})$ and higher curd firmness $\left(\mathrm{a}_{30}, 35.9\right.$ vs. $\left.29.0 \mathrm{~mm}\right)$ (Bonanno et al. 2013b). Instead, the superior ability of AA goats to synthetize de novo short and medium chain fatty acids (C4-C14) in the mammary gland tissue, observed also by Valenti et al. (2010), emerged only when the goats were fed with low-energy diet, whereas this difference between AA and AF goats disappeared when they received an energy supplemented diet (Bonanno et al. 2013b); the same occurred for the milk content of oleic acid, lower in AA milk only with low-energy diet (Bonanno et al. 2013b; Valenti et al. 2010), that indicates the lesser exigency of AA goats to mobilize fat depots, and confirms their more efficiency in energy utilization (Pagano et al. 2010; Valenti et al. 2010).

Based on these findings, the Girgentana goats carrying strong alleles at CSN1S1 loci are characterized by higher efficiency of nutrients utilization; thus, contrarily to goats with genotype associated with a lower $\alpha_{\mathrm{s} 1}$-casein synthesis, respond better to balanced high-nutrient diets in terms of milk yield, composition and cheese-making ability. Accordingly, in order to optimize dairy production in Girgentana goat farms, the suggestion is to provide adequate diets in energy and protein content to the high-producing CSN1S1 genotypes. On the contrary, in extensive farming systems based on grazing forage resources at pasture, the different CSN1S1 genotype of goats will be less important for ensuring high feeding efficiency and production. These indications could usefully direct the work of genetic selection of Girgentana breed to achieve high-producing genotypes exhibiting a more efficient feed utilization, which could express their potential in sustainable livestock production systems, contributing to a beneficial reduction in the environmental impact, especially limiting nitrogen excretions.

\subsection{Concluding Remarks}

Compare to commercial breeds, local breeds such as Girgentana goat are in disadvantage of economies of scale in breeding and marketing programmes, but on the other hand, play an important role in the utilization of the marginal agricultural resources and contribute to their environmental and socio-economic stability.

Application of a battery of genetic and nutrition tools, along with close cooperation with breeders and utilization of other tools such as innovative product marketing may allow small breeds to not only survive but also thrive.

The more recent actions, engaged to protect the Girgentana goat breed from the risk of extinction and recover its genetic and economic value, involved several studies on its genetic structure and management aspects that, synergically, have been able to optimize the productive traits of the breed. As a result, in Sicily today, 
there is a growing interest by dairy farmers in developing sustainable systems to provide consumers with authentic and safe dairy products manufactured with mono-breed milk of only Girgentana goats.

\section{References}

Ajmone-Marsan P, Colli L, Han JL et al (2014) The characterization of goat genetic diversity: towards a genomic approach. Small Ruminant Res 121:58-72

ASSONAPA (2014) Associazione Nazionale della Pastorizia. Available from http://www. assonapa.it/norme_ecc/Consistenze_Caprini.htm

Baumont R, Parche S, Meuret M et al (2000) How forage characteristics influence behaviour and intake in small ruminants: a review. Livest Prod Sci 64:15-28

Bonanno A, Di Grigoli A, Alicata ML et al (2007a) Effect of stocking rate on selective behaviour and milk production of Girgentana goats grazing a ryegrass and berseem clover mixture. Advanced nutrition and feeding strategies to improve sheep and goat nutrition, Options Mèditerranèennes série A: Séminanaires Méditerranéens, no 74, 351-357. ISSN 1016-121-X; ISBN 2-85352-363-2

Bonanno A, Di Grigoli A, Stringi L et al (2007b) Intake and milk production of goats grazing sulla forage under different stocking rates. Ital J Anim Sci 6(suppl. 1):605-607

Bonanno A, Finocchiaro R, Di Grigoli A et al (2007c) Energy intake effects at pasture on milk production and coagulation properties in Girgentana goats with different as $_{1}$-casein genotypes. In: Proceedings of the International Symposium of the International Goat Association (IGA), CRA-ZOE, Bella (PZ), Italy, pp 191-194

Bonanno A, Fedele V, Di Grigoli A (2008) Grazing management of dairy goats on Mediterranean herbaceous pastures. In: Cannas A, Pulina G (eds) Dairy goats feeding and nutrition. CAB International, Wallingford, UK, pp 189-220

Bonanno A, Di Grigoli A, Sardina MT et al (2009) Feed intake, milk composition and cheesemaking properties in Girgentana grazing goats with different genotype at $\alpha_{\mathrm{s} 1}$-casein and К-casein. Ital J Anim Sci 8(suppl 2):453

Bonanno A, Di Grigoli A, Di Trana A et al (2013a) Influence of fresh forage-based diets and

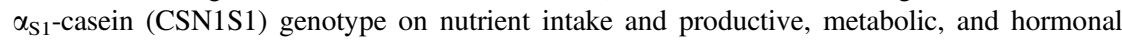
responses in milking goats. J Dairy Sci 96:2107-2117

Bonanno A, Di Grigoli A, Montalbano M et al (2013b) Effects of diet on casein and fatty acid profiles of milk from goats differing in genotype for $\alpha_{\mathrm{S} 1}$-casein synthesis. Eur Food Res Technol 237:951-963

Canon J, Garcia D, Garcia-Atance MA et al (2006) Geographical partitioning of goat diversity in Europe and the Middle East. Anim Genet 37:327-334

Caroli AM, Chiatti F, Chessa S et al (2006) Focusing on the goat casein complex. J Dairy Sci 89:3178-3187

Caroli AM, Chessa S, Erhardt GJ (2009) Invited review: milk protein polymorphisms in cattle: effect on animal breeding and human nutrition. J Dairy Sci 92:5335-5352

Criscione A, Bordonaro S, Moltisanti V et al (2016) Differentiation of South Italian goat breeds in the focus of biodiversity conservation. Small Ruminant Res 145:12-19

Delgado-Pertiñez M, Alcade MJ, Guzmán-Guerrero JL et al (2003) Effect of hygiene-sanitary management on goat milk quality in semi-extensive system in Spain. Small Rum Res 47:51-61

De la Torre Adarve G, Ramos Morales E, Serradilla JM et al (2009) Milk production and composition in Malagueña dairy goats. Effect of genotype for synthesis of aS1-casein on milk production and its interaction with dietary protein content. J Dairy Res 76:137-143

Di Grigoli A, Bonanno A, Alabiso M et al (2003) Effects of housing system on welfare and milk yield and quality of Girgentana goats. Ital J Anim Sci 2(suppl 1):542-544 
Di Gerlando R, Tortorici L, Sardina MT et al (2015) Molecular characterization of k-casein (CSN3) gene in Girgentana dairy goat breed and identification of two new alleles. Ital J Anim Sci 14:90-93

Di Trana A, Bonanno A, Cecchini S et al (2015) Effects of Sulla forage (Sulla coronarium L.) on the oxidative status and milk polyphenol content in goats. J Dairy Sci 98:37-46

Marletta D, Criscione A, Bordonaro S et al (2007) Casein polymorphism in goat's milk. Lait 87:491-504

Martin P, Szymanowska M, Zwierzchowski L et al (2002) The impact of genetic polymorphisms on the protein composition of ruminant milks. Reprod Nutr Dev 42:433-459

Martini M, Salari F, Altomonte I et al (2010) The Garfagnina goat: a zootechnical overview of a local dairy population. J Dairy Sci 93:4659-4667

Mastrangelo S, Sardina MT, Riggio V et al (2012) Study of polymorphisms in the promoter region of ovine b-lactoglobulin gene and phylogenetic analysis among the Valle del Belice breed and other sheep breeds considered as ancestors. Mol Bio Rep 39:745-751

Mastrangelo S, Tolone M, Sardina MT et al (2013a) Genetic characterization of the Mascaruna goat, a Sicilian autochthonous population, using molecular markers. Afr J Biotechnol 12:3758-3767

Mastrangelo S, Sardina MT, Tolone M et al (2013b) Genetic polymorphism at the CSN1S1 gene in Girgentana dairy goat breed. Anim Prod Sci 53:403-406

Mastrangelo S, Portolano B, Di Gerlando R et al (2017a) Genome-wide analysis in endangered populations: a case study in Barbaresca sheep breed. Animal 11:1107-1116. https://doi.org/10. $1017 / \mathrm{S} 1751731116002780$

Mastrangelo S, Tolone M, Montalbano M et al (2017b) Population genetic structure and milk production traits in Girgentana goat breed. Anim Prod Sci 57:430-440

Naderi S, Rezaei HR, Pompanon F et al (2008) The goat domestication process inferred from large-scale mitochondrial DNA analysis of wild and domestic individuals. Proc Natl Acad Sci USA 105:17659-17664

Negrini R, D'Andrea M, Crepaldi P et al (2012) Effect of microsatellite outliers on the genetic structure of eight Italian goat breeds. Small Ruminant Res 103:99-107

Nicoloso L, Bomba L, Colli L et al (2015) Genetic diversity of Italian goat breeds assessed with a medium-density SNP chip. Genet Sel Evol 47:1. https://doi.org/10.1186/s12711-015-0140-6

Pagano RI, Pennisi P, Valenti B et al (2010) Effect of CSN1S1 genotype and its interaction with diet energy level on milk production and quality in Girgentana goats fed ad libitum. J Dairy Res 77:245-251

Palmeri M, Mastrangelo S, Sardina MT et al (2014) Genetic variability at as2-casein gene in Girgentana dairy goat breed. Ital J Anim Sci 13:116-118

Pariset L, Cappuccio I, Ajmone-Marsan P et al (2006) Assessment of population structure by single nucleotide polymorphisms (SNPs) in goat breeds. J Chromatogr B 833:117-120

Park YW, Jurez M, Ramos M et al (2007) Physico-chemical characteristics of goat and sheep milk. Small Rum Res 68:88-113

Portolano B, Finocchiaro R, Todaro M (2004) Demographic characterization and genetic variability of the Girgentana goat breed by the analysis of genealogical data. Ital J Anim Sci $3: 41-45$

Russo V, Fontanesi L, Scotti E et al (2007) Analysis of melanocortin 1 receptor (MC1R) gene polymorphisms in some cattle breeds: their usefulness and application for breed traceability and authentication of Parmigiano Reggiano cheese. Ital J Anim Sci 6:257-272

Sacchi P, Chessa S, Budelli E et al (2005) Casein haplotype structure in five Italian goat breeds. J Dairy Sci 88:1561-1568

Sardina MT, Ballester M, Marmi J et al (2006) Phylogenetic analysis of Sicilian goats reveals a new mtDNA lineage. Anim Genet 37:376-378

Sardina MT, Tortorici L, Mastrangelo S et al (2015) Application of microsatellite markers as potential tools for traceability of Girgentana goat breed dairy products. Food Res Int $74: 115-122$ 
Scintu MF, Piredda G (2007) Typicity and biodiversity of goat and sheep milk products. Small Rum Res 68:221-231

Siwek M, Finocchiaro R, Curik I et al (2011) Hierarchical structure of the Sicilian goats revealed by Bayesian analyses of microsatellite information. Anim Genet 42:93-95

Todaro M, Scatassa ML, Giaccone P (2005) Multivariate factor analysis of Girgentana goat milk composition. Ital J Anim Sci 4:403-410

Tortorici L, Di Gerlando R, Mastrangelo S et al (2014) Genetic characterization of CSN2 gene in Girgentana goat breed. Ital J Anim Sci 13:720-722

Vacca GM, Ali HOAB, Carcangiu V et al (2009) Genetic structure of the casein gene cluster in the Tunisian native goat breed. Small Ruminant Res 87:33-38

Valenti B, Pagano RI, Pennisi P et al (2010) Polymorphism at $\alpha$ s1-casein locus. Effect of genotype diet $\times$ interaction on milk fatty acid composition in Girgentana goat. Small Rumin Res 94:210-213

Zeder MA, Hesse B (2000) The initial domestication of goats (Capra hircus) in the Zagros mountains 10,000 years ago. Science 287:2254-2257 